\title{
The Effect of Work Environment, Competence, and Motivation on Employee's Performance in Electronic Companies in the Industrial District of Bekasi Regency
}

\author{
Sabil $^{1}$, Suhartono ${ }^{2}$, Slamet Heri Winarno ${ }^{3}$, Octa Pratama Putra ${ }^{4}$, Dwiyatmoko Puji Widodo ${ }^{5}$ \\ 1, 2, 3, 4, 5 Universitas Bina Sarana Informatika \\ e-mail: 1 sabil.sbl@bsi.ac.id, ${ }^{2}$ suhartono.sht@bsi.ac.id, ${ }^{3}$ slamet.smh@bsi.ac.id, ${ }^{4}$ octa.opp@bsi.ac.id, \\ ${ }^{5}$ dwiyatmoko.dpw@bsi.ac.id
}

\begin{tabular}{ccc}
\hline Diterima & Direvisi & Disetujui \\
$07-12-2020$ & $13-01-2021$ & $19-01-2021$ \\
\hline
\end{tabular}

\begin{abstract}
Employee performance is an important element to assess the level of success of the company is running its business. Many factors can affect employee performance, including the environment, work, competence, and employee motivation. This study aims to explore the relationship between the influence of these three factors on employee performance. The sample of respondents selected were employees who worked at several electronic companies in the Bekasi Industrial Area, West Java, Indonesia. This study uses structural equation modeling (SEM) and path analysis to test the level of influence of the variables used. The use of 183 employees who come from different characteristics, age, sex, length of work, education, and income are used to test the effect of the work environment, competence, and motivation on performance. The results showed that performance was more significantly influenced by the work environment and motivation as intervening, while competence did not significantly influence performance. Motivation also directly influences performance. Companies must be able to create attractive work environments so that employees can be motivated and make optimal use of employee competency planning. This study focuses more on how the work environment, competence, and motivation affect performance both partially and simultaneously.
\end{abstract}

Keywords: Work Environment, Competence, Motivation, Employee's Performance

\section{INTRODUCTION}

The growth of the industrial world in the current millennial era is still increasing very rapidly. Besides, there are many new companies (startups) that have grown up and moved rapidly as keeping along with the high asset rate. For this reason, strong resources are needed, one of them is from human resources itself. Many factors affect human resources; so that they continue to improve their performance (Sidanti, 2015).

While for the other researchers, (Z. Hidayat \& Taufiq, 2012) show that there is a significant influence of work environment variables and work discipline and work motivation simultaneously which affects the employee's performance. (Anshari et al., 2019)

It is said that the employee's competency is the dominant variable affecting its performance. Electronic companies in industrial areas in the Bekasi district also shows the interrelationship of influence, work environment, competence, and working motivation toward the employee's performance (Pawirosumarto, 2017). It assumes that it is characterized by a person that results in ineffective and/or superior performance in a job (Charda, 2015).

Competence is so important for the business world as the basis of the employee's recruitment. Some experts even claim that a high IQ (Intelligence Quotient) person does not guarantee to achieve success
(Andiri et al., 2017). He even states that it is necessary to replace the intelligence tests with tests based on competence (Kasim, 2012).

Motivation is a conscious effort to move, direct, and maintain one's behavior (Kasim, 2012). So, he or she will be compelled to act of doing something, then achieving certain results or goals later. Human needs are arranged hierarchically; from the lowest to the highest. If one type of person's need has been fulfilled, then it is not going to be able to be used as a motivator (F. Hidayat, 2009).

Several factors to influence work motivation are the high-pay, a healthy work environment, occasionally having recreational opportunities (Hermawati, 2012). Pullins in (Krisdiyanto, 2010) motivation of a person plays an important role in the performance of employees' productivity. From all the beforehand explanations, it can be concluded, motivation has a relationship with several other variables in improving organizational performance.

Then, the work environment states where employees will carry out activities to do their particular job. Certainly, a conducive work environment provides a sense of feeling secure and it

allows employees to work optimally. Also, the work environment can affect employee transition.

Performance is the result of the quality and quantity of working that can be achieved by an employee in 
carrying out the job description under the responsibilities given to the employee. Employees' performance (working performance) is the work quality and quantity achieved by an employee in carrying out their things to do following the responsibilities given to him (Mangkunegara, 2005). On the other hand, the work performance of the assessment is an attempt by the leader to assess the work of the subordinates.

(Pawirosumarto, J. D. S, 2017) in his research mentioned the importance of competence and motivation in fostering employee performance, but did not mention how work environmental factors influence it. Likewise research (Hidayat, Z., \& Taufiq, M., 2012) (Kasim, 2012) which only implies that performance is quite influenced by ability and motivation factors alone without looking at other factors.

Based on this, this study tries to measure factors from the work environment in influencing employee performance in addition to competence and motivation.

\section{METHODS}

This research method uses a questionnaire designed to collect data about factors that affect work motivation. Data is collected from 183 employees of electronic companies in the Bekasi Regency Industrial estate. The collected data is analyzed by using Structural Equation Modelling (SEM) with AMOS. The renewal of this research that, research has never been done on electronic companies in the Bekasi industrial area, and the latest finding tells that, the electronic companies can improve the work environment, improve competence and motivate employees to increase their performance.

The hypothesis of this research shows that: $\mathrm{H} 1=$ Working environment has a positive effect on employee work motivation, $\mathrm{H} 2=$ Working environment has a significant effect on employee performance, $\mathrm{H} 3$ = The competence has a good effect on employee work motivation, $\mathrm{H} 4$ = The competence has an excellent effect on performance employees, H5 $=$ Motivation has a big effect on employee performance.

\section{RESULT AND DISCUSSIONS}

The respondents in this study are the employees in the industrial area in the Bekasi district. The individual characteristics of respondents in this study include several things: age, sex, marital status, education level, employee age.

The results of the study are described by a model that contains calculated values, as shown in Figure 1.

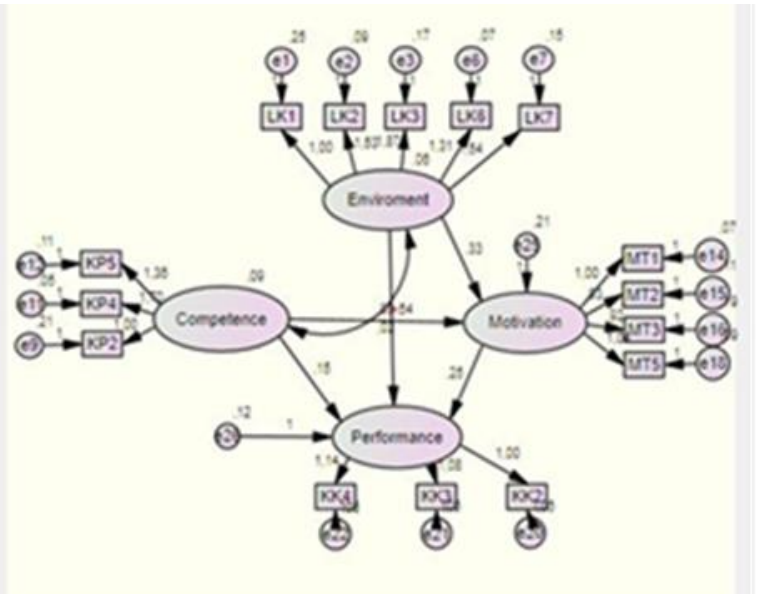

Sources: Data of research (2019)

Figure 1. Research Result Model

The critical value limit (cut off) can be used the goodness of fit test as done in research (Widodo, 2000) which results in the compatibility test value in table 1.

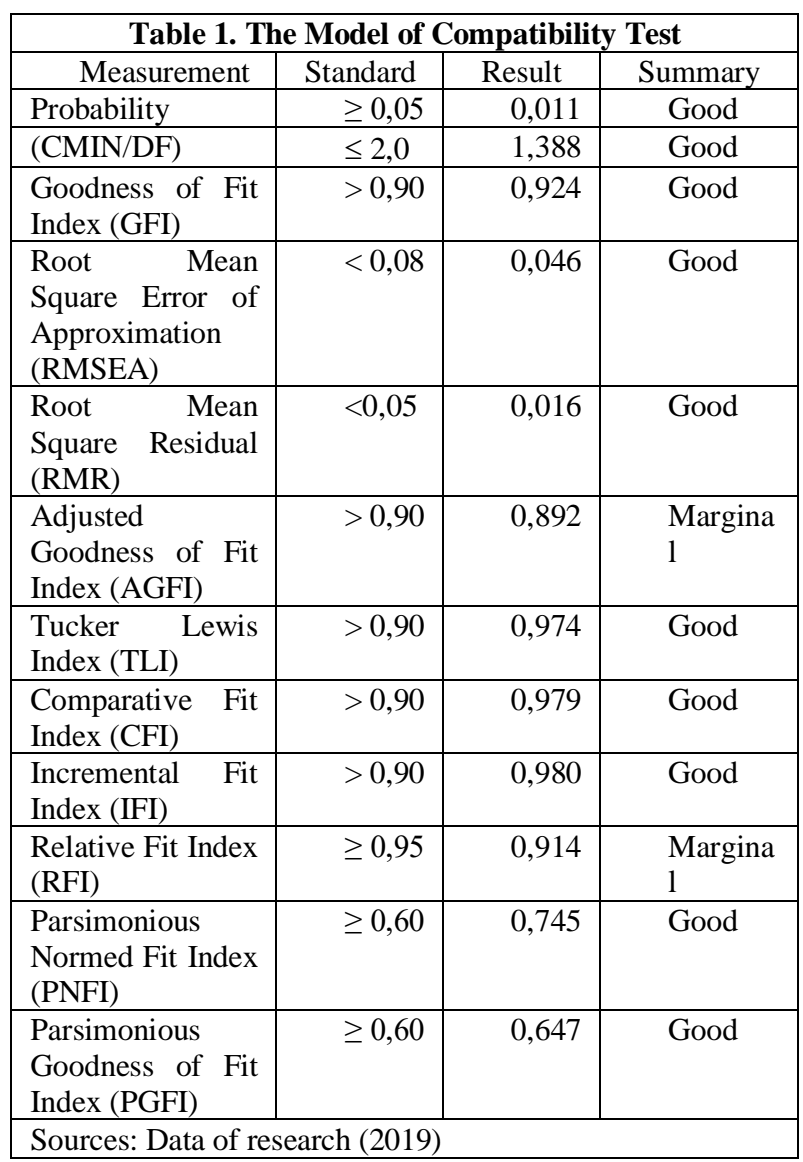

The model is considered to represent data if the CMIN/DF value of the test results is more than 2.0. Based on the results of calculations on the model, the value of CMIN/DF is 1.388 with a significant value of 0.11 . The sig. value of the test result is bigger than 0.05 , which means Ho is not rejected and it is concluded that the model is feasible to be used and it can represent the data. The testing states RMSEA (Root Mean Squares Error of Approximation) 0.046 is less than 0,08. So, it 
indicates the model is suitable to be used.

The required Goodness of Fit Index (GFI) value from 0 to 1 , the more the GFI as its value, the better model is formed. While the expected GFI value is more than 0.9. Based on the calculation results, the GFI result of the model is 0.924 , which means that the model formed is included in the eligible criteria. It is stated so because it has a GFI value > 0.9. The Adjust Goodness of Fit Index (AGFI) is in the range of 0 to 1 , the more the AGFI value, it means the better the model is formed. Regarding it, the expected AGFI value is more than 0.8. Based on calculations on the model, the AGFI value is 0.892, which means the model formed is included in the eligible criteria.

It is implied as to the previous statement because it has an AGFI value of $>0.8$. Comparative Fit Index (CFI) is in the range between 0 to 1 , the more the CFI value, so it will be the higher the CFI value. It is assumed that the model is suitable. The results of the model testing show the CFI value is 0.979 . This current value is large enough because it is closer to 1 so that it can be surely declared that, the model in this study is fit.

Tucker Lewis Index (TLI) compares a model multiplied against the model baseline. Afterward, the required TLI value must be higher or equal to 0.95 . The test results show, the TLI value states 0.974 , this value is more than 0.95 . The resulting testing shows the value of TLI will be 0,974 . Its value is certainly more than 0,95 , which exactly means the research model is acceptable.

\begin{tabular}{|c|r|r|c|l|}
\hline \multicolumn{5}{|c|}{ Table 2. The Hypothesis Test Result } \\
\hline Hypothesis & $t$-Value & $\begin{array}{r}\text { Criti } \\
\text { cal } \\
\text { Valu } \\
\text { e }\end{array}$ & $P$ & Result \\
& & 1,96 &, 054 & Rejected \\
\hline H1 & 1,924 & 1,96 & $* * *$ & Accepted \\
\hline H3 & 5,420 & 1,96 & $* * *$ & Accepted \\
\hline H2 & 3,903 & 1,96 & $* *$ & Accepted \\
\hline H5 & 3,619 & 1,96 & $* * *$ & Rejected \\
\hline H4 & 1,190 & 1,96 &, 234 & Re \\
\hline \multicolumn{7}{|c|}{ Sources: Data of research (2019) } \\
\hline
\end{tabular}

The first hypothesis testing $\left(\mathrm{H}_{1}\right)$ is done by comparing the $t$-value which is 1.924 smaller than 1.96 and a $p$-value of 0.054 greater than 0.05 so that $\mathrm{H}_{0}$ is accepted and it can be concluded that the work environment has no positive and significant effect on employee motivation $\left(\mathrm{H}_{1}\right)$. This is contrary to the research of (Z. Hidayat \& Taufiq, 2012), which states that work motivation is strongly influenced by elements of the work environment. The ineffectiveness of the work environment is due to the working conditions and atmosphere felt by employees unable to generate a new, more energetic spirit for employees to work. It can be said that there is an element of boredom in employees.

The results of the analysis of the second hypothesis $\left(\mathrm{H}_{2}\right)$, obtained $t$-value of 3.903 is greater than 1.96 , and the $p$-value is marked with a triple star symbol (***) and the confirmed value is less than 0.05. Thus, $\mathrm{H}_{0}$ is rejected and concluded that the work environment has a good effect on employee performance $\left(\mathrm{H}_{2}\right)$. For some employees, the current working environment has made them aware of the importance of work with improved performance results. This result is also in line with the research of who said that performance is significantly influenced by work environment factors.

In the third hypothesis $\left(\mathrm{H}_{3}\right)$, the $t$-value of 5.420 is greater than 1.96 and the $p$-value is marked with a triple star symbol (***) and the value is less than 0.05 , thus $\mathrm{H}_{0}$ is rejected and it is concluded that the competency owned by employees positively and significantly influence work motivation $\left(\mathrm{H}_{3}\right)$. Employees who have excellence and expertise in their fields will certainly encourage them to be more enthusiastic about working absolutely.

The results of the fourth hypothesis analysis $\left(\mathrm{H}_{4}\right)$ obtained at-value of 1.190 are smaller than 1.96 and the p-value of 0.234 is greater than 0.05 , so $\mathrm{H}_{0}$ is accepted and it can be said that employee competency has no positive and significant effect on performance $\left(\mathrm{H}_{4}\right)$. It is proven that the expertise of employees at this company is only used to carry out the job description to them only. They assume as long as the work has been completed, then their responsibility is also over, too.

Whereas in the fifth hypothesis $\left(\mathrm{H}_{5}\right)$, the $t$-value of 3,619 is greater than 1.96 and the $p$-value is marked with a triple star symbol (***) and the value is less than 0.05 so $\mathrm{H}_{0}$ is rejected and concluded that motivated employees have an excellent effect on performance $\left(\mathrm{H}_{5}\right)$. that well-motivated employees will easily complete all kinds of work by providing good results.

The influence of the work environment on motivation reflects shows that, each worker does not want to have joyful of working. So, company management must make significant changes to the working environment. The purpose is to make it more comfortable with workers so that they will be having the enjoyment of working. On the other hand, each employee/worker at this company is only trying to improve the quality in him/herself and does not show to improve the performance toward the management. Policies that can be implemented by the company are by placing employees by their competencies to carry out the tasks given, which are believed to be able to improve their performance.

The analysis of the direct and indirect effects of the research variables. Intervening variables play a role in determining the total value of the overall stream (total effect). The magnitude of the effect of this intervening variable can be seen that there is an influence of the work environment on performance through motivational variables of 0.414 . While the total effect of competence on performance through intervening motivation variables is 0.271 .

The results showed that the work environment did not fully affect the work motivation of employees, this could be caused by changes that occur in the work environment, it is believed that it does not encourage employees to carry out work. This contradicts the results of research (Triastuti, 2018) which states that 
one of the factors that trigger employee development is the support of a good work environment.

But on the other hand, the work environment has a significant effect on improving performance. Whatever the form of the existing work environment, it turns out that it has produced a good work ethic for employees and this is in line with research (Dhermawan, 2012) and (Dewi, 2013).

Another factor that influences motivation and performance at this company is employee competence. It is believed that the higher the competence of a company's employees will increase morale and good work results. (Triastuti, 2018) and (Dhermawan, 2012) also say the same thing, that competence is an important thing that must be owned by employees in improving their work performance.

\section{CONCLUSIONS}

It can be concluded that the endogenous variables of work motivation are significantly influenced by employee competency factors. While the employee performance variable is significantly affected by work environment factors and employee work motivation.

Many factors that cause work environment factors which not affect the work motivation in this condition. It has happened because of the feeling of boredom at work.

The competencies that are believed to have an impact on improving employee performance have not been proven to affect yet. This reflects the skill of employees is only used to do his or her job description only, yet he or she does not think the quality of the results.

Seeing this condition, companies should think more about creating conditions for a comfortable work environment for employees to be more motivated to work. Also, it is better to appreciate the competencies of employees by providing the appropriate working instruction with the skill that is expected to produce better and increased output. For further research, it may use the wage policy as an additional variable to determine work productivity in electric companies in Bekasi.

\section{REFERENCES}

Andiri, L., Jajat, \& Sultoni, K. (2017). Hubungan Kecerdasan Emosi Dengan Prestasi Akademik Mahasiswa Olahraga. Terapan Ilmu Keolahragaan, 2(2), 137-141.

Anshari, A. R. I., Mus, A. R., \& Serang, S. (2019). Pengaruh Kompetensi, Motivasi Kerja dan Lingkungan Kerja terhadap Kinerja Karyawan pada PT Datascrip Cabang Makassar. Jurnal Ilmu Ekonomi, 2(3).
Charda, U. (2015). Karakteristik Undang-Undang Ketenagakerjaan Dalam Perlindungan Hukum Terhadap Tenaga Kerja. Wawasan Hukum, 32(1), 1-21.

Dewi, Sari Kusuma. (2013). Pengaruh Lingkungan Kerja Terhadap Kinerja Karyawan Melalui Motivasi. Jurnal Ilmiah Manajemen, 1(4), 10551065

Dhermawan, Anak Agung Ngurah Bagus dkk. (2012). Pengaruh Motivasi, Lingkungan Kerja, Kompetensi, Dan Kompensasi Terhadap Kepuasan Kerja Dan Kinerja Pegawai Di Lingkungan Kantor Dinas Pekerjaan Umum Provinsi Bali. Jurnal Manajemen, Strategi Bisnis, dan Kewirausahaan , 6(2), 173-184

Hermawati, A. (2012). Pengaruh Motivasi Dan Kemampuan Terhadap Prestasi Kerja Pegawai Dinas Pendidikkan Pemerintah Kota Batu. Dinamika Dotcom, 3(1), 29-41.

Hidayat, F. (2009). Motivasi Pekerja Pada Proyek Konstruksi di Kota Bandung. Media Teknik Sipil, 9, 57-70.

Hidayat, Z., \& Taufiq, M. (2012). Pengaruh Lingkungan Kerja dan Disiplin Kerja serta Motivasi Kerja Terhadap Kinerja Karyawan Perusahaan Daerah Air Minum (PDAM) Kabupaten Lumajang. Jurnal WIGA, 2(1), 7997.

Kasim, K. (2012). Pengaruh Motivasi Dan Kemampuan Serta Komitmen Terhadap Kinerja Pengurus Upk Pnpm Mandiri Perdesaan Di Kabupaten Lumajang. WIGA, 2(1), 1-17.

Krisdiyanto, A. (2010). An Analysis Of Factors Influencing Motivation And Its Impact On Employees Performance Improvement. Ilmu Ekonomi ASET, 1-27.

Mangkunegara, A. . A. P. (2005). Manajemen Sumber daya Manusia Perusahaan. PT Remaja Rosdakarya.

Pawirosumarto, J. D. S. (2017). Pengaruh Kompetensi, Motivasi Kerja Dan Disiplin Kerja Terhadap Kinerja Guru (Studi Kasus Di Smk Karya Fajar Kecamatan Petir Kabupaten Serang Provinsi Banten). SWOT, 7(2), 239-256.

Sidanti, H. (2015). Pengaruh Lingkungan Kerja, Disiplin Kerja Dan Motivasi Kerja Terhadap Kinerja Pegawai Negeri Sipil di Sekretariat Dprd Kabupaten Madiun. Jurnal JIBEKA, 9(1), 44-53.

Triastuti, Dinie Anisa. (2018). Pengaruh Lingkungan Kerja, Kompetensi Dan Iklim Organisasi Terhadap Kinerja Pegawai. Journal of Management Review, 2(2), 203-208

Widodo, Prabowo, P. (2006). Langkah-Langkah Dalam SEM Pemodelan Persamaan Struktural, Seri SEM. Jakarta. 